\title{
Moral character effects in endorser perception
}

\author{
Joseph W. CHANG \\ University of Massachusetts, Dartmouth, USA \\ joseph.chang@umassd.edu
}

\begin{abstract}
This research consists of two experimental studies investigating the influence of moral character on endorser perception, and the influence of perceiver characteristics on tarnished endorser perception and brand evaluations. Perceiver characteristics are discussed from the perspectives of dispositional tendency, innate moral intuitions and self-location. The first study compared the influences of moral character and warmth on endorser perception. The second study examined the impact of perceiver characteristics on tarnished endorsers and brand evaluations. The findings reveal that moral character is more influential than warmth on endorser evaluations. Tarnished endorsers with immoral character exert more negative influence than tarnished endorsers with coldness character on brand evaluations. Innate moral intuitions and self-location moderate brand evaluations. High-morality consumers and heart-locators are more vulnerable than low-morality and brain-locators to the brands endorsed by tarnished endorsers, respectively.
\end{abstract}

Keywords: dispositional tendency, innate moral intuition, self-location, moral character, warmth, celebrity endorser, brand evaluation.

Please cite the article as follows: Chang, J.W. (2017), "Moral character in endorser perception", Management and Marketing. Challenges for the Knowledge Society, Vol. 12, No. 2, pp. 171-188. DOI 10.1515/mmcks-2017-0011.

\section{Introduction}

In social psychology, both moral character and warmth were verified as the two most dominating personality traits in person perception (Fiske et al., 2007; Goodwin et al., 2014). As with person perception, the influences of moral character and warmth on endorser perception should also be impactful. However, while extant research in endorsements has verified a variety of effective endorser characteristics (e.g., attractiveness, expertise, likability, trustworthiness) (e.g., Belch and Belch, 2013), the impacts of moral character and warmth on endorser perception have not been investigated yet.

Additionally, the discussion about endorser perception should be more thorough if the personality characteristics of perceivers (i.e., consumers) are also considered. For example, will consumers favoring emotional considerations (i.e., self-location) (Fetterman and Robinson, 2013) be more sensitive to immoral behaviors and evaluate brands less favorably? Will consumers with negative dispositional tendency (Hepler and Albarracín, 2013) evaluate immoral behaviors and brands more negatively? Will consumers having higher moral intuitions (Graham et al., 2009) be more sensitive to immoral behaviors and evaluate brands less favorably?

Therefore, this research advances endorsement research by examining the moderations of the characteristics of endorsers (i.e., moral character and warmth) 
and perceivers (i.e., dispositional tendency, innate moral intuitions, and selflocation). With two experimental studies, we demonstrate that moral character is more influential than warmth on endorser evaluations. Tarnished endorsers with immoral character (vs. coldness) exert more negative influence on brand evaluations. Except for dispositional tendency, innate moral intuitions and selflocation moderate brand evaluations. Finally, theoretical and managerial implications are discussed based on the research findings.

\section{Theoretical framework}

\section{The impacts of endorser characteristics on brand evaluations}

The utilization of celebrity endorsers as spokespersons for brands has long been the fashion in advertising. Extant endorsement research documents that the endorser characteristics of attractiveness, expertise, familiarity, likability, popularity, and trustworthiness enhance consumer attitudes toward the endorsed brands (Amos et al., 2008; Belch and Belch, 2013; Kahle and Homer, 1985; Lee and Koo, 2015; Liu and Brock, 2011; Ohanian, 1990, 1991; Petty et al., 1983; Pikas et al., 2012; Rice et al., 2012; Spry et al., 2011; Silvera and Austad, 2004). The extant research results about the dominance of these endorser characteristics are congruent. Amos and colleagues (2008) propose that trustworthiness, expertise, and attractiveness capture the most influential source effects. Belch and Belch (2013) depict that popularity (or likeability), physical attractiveness, and expertise are primary characteristics. Further, the dominance of endorser characteristics changes overtime. Attractiveness exerts its dominance in immediate conditions, whereas expertise becomes more influential in delayed conditions (Eisend and Langner, 2010).

The discussion about the negative impacts of tarnished celebrity endorsers on brand evaluations has also become a fashion. Recent research uncovers that disgraced celebrity endorsers involved in scandals are detrimental to the perception of endorsed brands (Fong and Wyer, 2012; Lee et al., 2016; Lee et al., 2015; Till and Shimp, 1998) and the stock returns of firm value (Bartz et al., 2013; Knittel and Stango, 2014; Louie and Obermiller, 2002; Money et al., 2006). Moreover, blameworthy (or culpable) endorsers induce more negative reactions in stock returns (Louie et al., 2001). Negative publicity information instigates more negative impacts on endorsers congruent with the brands that they endorsed (Carrillat et al., 2013; Fleck et al., 2012; Thwaites et al., 2012).

Latest research in person perception verifies moral character (Goodwin et al., 2014) and warmth (Fiske et al., 2007; Fiske et al., 2002) as the two most dominating personality traits. Moral character consists of the traits of courageous, principled, dedicated, reliable, and honest, whereas warmth consists of the traits of social, happy, agreeable, funny, and playful. Moral character is defined as the normal pattern of thought and action in relation to moral choice (Kupperman, 1991). Moral character information is proven to be more influential on person perception than is warmth information (Goodwin et al., 2014). As with person perception, we propose that both moral character and warmth are primary endorser characteristics. In 
comparison, moral character pre-dominates warmth on advertising and brand evaluations. As a result, negative moral character (or immorality) information instigates more negative impacts than negative warmth (or coldness) information on advertising and brand evaluations. In other words, endorsers tarnished in moral character (warm-immoral) are more detrimental than endorsers disgraced in warmth (moral-cold) on endorsed advertising and brand evaluations. Therefore,

H1: Moral character dominates warmth on endorser perception.

H2: Immoral character instigates more negative impacts than coldness on advertising and brand evaluations.

\section{The impacts of perceiver characteristics on brand evaluations}

In addition to the effects of endorser characteristics, extant endorsement research has also verified the perceiver effects of self-construals (Polyorat and Alden, 2005; Wang et al., 2000; Zhang, 2009; Zhang et al., 2011), self-regulatory (Kareklas et al., 2012), self-concept (Chang, 2010), implicit self-theory (Park and Roedder John, 2012), self-empowerment (Tsai and Tsai, 2011), and explicit and implicit memory (Shapiro and Krishnan, 2001).

In contrast, discussion about the moderation of perceiver characteristics on tarnished celebrity endorsers has also been investigated. It is documented that the perceiver characteristics of attribution styles, celebrity identification, brand commitment, and personal involvement moderate the negative impacts of scandals on brand evaluations (Ahluwalia et al., 2000; Thwaites et al., 2012; Um, 2013). Scandals are more influential on perceivers who make dispositional (vs. situational) attributions and are low in brand commitment and celebrity identification.

Extant research in social cognition has recently documented that the dispositional tendency (Hepler and Albarracín, 2013), innate moral intuitions (Graham et al., 2009), and self-location (Fetterman and Robinson, 2013) of perceivers moderate perceivers' social judgments. As with social cognition, we propose that these perceiver characteristics moderate the impacts of tarnished endorsers on brand evaluations as follows.

\section{Dispositional tendency}

In personality psychology, the dispositional tendency theory depicts that perceivers are different in the dispositional tendency intrinsically exerting positive or negative attitudes (Hepler and Albarracín, 2013). Perceivers' attitudes toward social stimuli can be partly predicted by the intrinsic personality of dispositional tendency, without even having to consider the specific attitudes. In other words, attitudes toward unrelated stimuli may be positively correlated due to the influence of perceivers' personality. Thus, an attitude is in fact a synergy of the function of an object's properties and the properties of the perceiver. The dispositional attitudes are operationally captured by the 16-item Dispositional Attitude Measure (DAM). The DAM scores are proven to be positively and negatively correlated with positive and negative affect traits, respectively, as well as the valence of the Big 5 and optimism (Hepler and Albarracín, 2013). 
As endorsers are social objects, we propose that dispositional attitudes moderate endorser perception. Perceivers with negative (vs. positive) dispositional tendency more (vs. less) unfavorably evaluate tarnished (moral-cold or warmimmoral) endorsers and the advertising and brands that the tarnished celebrities endorse. However, while evaluating social objects differently in extent, the perceptual norms of perceivers with positive and negative dispositional tendency are identical. In comparison, the perceptual norms of perceivers with positive and negative dispositional tendency are relatively more positively and negatively anchored, respectively (Hepler and Albarracín, 2013). In other words, while negative (vs. positive) dispositional tendency perceivers tend to more (vs. less) unfavorably evaluate social objects, the dispositional tendency doesn't imply that negative (vs. positive) dispositional tendency perceivers are more (vs. less) sensitive to, and yield more (vs. less) attitude change on, social stimuli. In other words, perceivers with positive and negative dispositional tendency shall yield identical attitude changes on brand evaluations. Perceivers with negative (vs. positive) dispositional tendency both more (vs. less) unfavorably evaluate the brands before and after the impact of the tarnished endorsers. The difference in prior brand evaluations between perceivers with positive and negative dispositional tendency is counterbalanced by the difference in posterior brand evaluations. Therefore,

H3a: Perceivers with negative dispositional tendency more unfavorably evaluate the brands endorsed by tarnished endorsers than perceivers with positive dispositional tendency.

H3b: Tarnished endorser information instigates identical negative impacts on positive and negative dispositional tendency perceivers' brand evaluations.

\section{Innate moral intuitions}

In personality psychology, morality is defined as "perspective judgments of justice, rights, and welfare pertaining to how people ought to relate to each other" (Turiel, 1983, p. 3). The innate moral intuition theory depicts that moral intuitions derive from innate psychological mechanisms consisting of values and practices coevolving with cultural institutions and practices (Graham et al., 2009; Richerson and Boyd, 2005). The moral intuitions are modifiable mechanisms (Marcus, 2004) providing subjects with the moral foundations to build on as they transmit cultural values and perceive social objects. As the endorser evaluation of this research is morality relevant, the innate moral intuitions of perceivers should coevolve with the perception of tarnished celebrity endorsers. We propose that perceivers with higher moral intuitions should be more sensitive to, and more unfavorably evaluate, tarnished endorsers and the advertising and brands endorsed by the tarnished endorsers. Therefore,

H4: High-morality perceivers more unfavorably evaluate tarnished endorsers and the advertising and brands endorsed by the tarnished endorsers than low-morality perceivers. 


\section{Self-location}

Extant research in personality psychology documents that conceptual metaphors (e.g., "friendly is warm") are shared by members of a culture (Lakoff, 1986), are largely universal across cultures, and constrain thinking and behavior across individuals (Landau et al., 2010). Metaphor representation theory suggests that conceptual metaphors guide thought, emotion, and behavior (Lakoff and Johnson, 1999). Based on the metaphor representation theory, self-location theorists depict that body metaphors are consequential in understanding individual differences in cognition, emotion, and performance (Fetterman and Robinson, 2013). Brainlocators are thought to be rational, logical, and cold, whereas heart-locators are emotional, feminine, and warm. In comparison, heart- (vs. brain-) locators more (vs. less) favor emotional over rational considerations and experience greater negative emotion on high stressor days. Based on the self-location theory, we propose that heart- (vs. brain-) locators are more sensitive to, and, thus, more (vs. less) unfavorably evaluate, tarnished celebrity endorsers and the advertising and brands endorsed by the tarnished endorsers. Thus,

H5: Heart-locators more unfavorably evaluate tarnished endorsers and the brands and advertising endorsed by tarnished endorsers than brainlocators.

Two experimental studies with 135 and 71 subjects, respectively, were conducted to verify these hypotheses. Study 1 compared the dominance of moral character and warmth on endorser perception (H1). Study 2 examined the dominance of immoral character (H2) and the impact of perceiver characteristics on the cause and effect relationship between tarnished endorsers and brand evaluations (H3, $\mathrm{H} 4$ and $\mathrm{H} 5$ ).

\section{Study 1}

Method

The data was collected online via Amazon Mechanical Turk (or M-Turk) with Qualtrics questionnaires. Overall, 135 U.S. residents ( 69 females, 66 males; $M_{\text {age }}=$ $32.36, S D=9.36$ ) participated in the 2 (moral character: good vs. bad) $\mathrm{x} 2$ (interpersonal warmth: warm vs. cold) within-subjects experimental design. The participants were explicitly provided with information about the "interpersonal warmth" and the "moral character" of four different brand endorsers, and were asked to indicate their global impressions of each brand endorser on a 9-point semantic differential scale anchored by "very negative (1)" and "very positive (9)" (Goodwin et al., 2014). The four trait-combinations are (a) good moral character and interpersonally warm, (b) good moral character, but interpersonally cold, (c) bad moral character, but interpersonally warm, and (d) bad moral character and interpersonally cold. To control order-effect bias, the four trait-combinations were presented with four orders (i.e., abcd, bcda, cdab and dabc), and the participants were randomly assigned to one of these four conditions. 


\section{Test of hypotheses and discussion}

Hypothesis 1 states that moral character dominates warmth on endorser perception. One-way ANOVAs yielded no order-effect on global impressions across the four conditions ( $p s>.12$; see Table 1). Therefore, the orders of the four conditions were collapsed and combined for analysis. Within-subjects analyses revealed significant main effects of both moral character $\left(M_{\text {moral }}=6.71, M_{\text {immoral }}=2.53, F(1,134)=\right.$ 846.16, $\left.p<.001, \eta_{p}^{2}=.86\right)$ and warmth information $\left(M_{\text {warm }}=5.62, M_{\text {cold }}=3.62, F(1\right.$, $\left.134)=373.89, p<.001, \eta_{p}^{2}=.66\right)$ on endorser impressions. In comparison, moral character information was more impactful than warmth information on endorser impressions. Moreover, the moral-cold endorser was more favorably evaluated than immoral-warm endorser $\left(M_{\text {moral-cold }}=5.40, M_{\text {immoral-warm }}=3.22, t(134)=12.47, p\right.$ $<.001)$. There was also an interaction between moral character and warmth $(F(1$, $134)=48.31, p<.001, \eta_{p}^{2}=.27$ ), reflecting that warmth information was more impactful for moral than for immoral endorsers (see Figure 1).

Table 1. Tests of order-effect: Means and standard deviation

\begin{tabular}{|c|c|c|c|c|c|c|c|}
\hline Characters & \multicolumn{5}{|c|}{ Orders of display } & \multirow{2}{*}{$\begin{array}{l}F(1, \\
131)\end{array}$} & \multirow{2}{*}{$\begin{array}{l}\text { Sig. } \\
(p)\end{array}$} \\
\hline & abcd & bcda & cdab & dabc & Overall & & \\
\hline $\begin{array}{l}\text { Moral-Warm } \\
\text { (a) }\end{array}$ & $\begin{array}{c}7.71 \\
(1.25)\end{array}$ & $\begin{array}{c}8.21 \\
(1.02)\end{array}$ & $\begin{array}{c}8.00 \\
(1.13)\end{array}$ & $\begin{array}{c}8.15 \\
(1.06)\end{array}$ & $\begin{array}{c}8.01 \\
(1.13)\end{array}$ & 1.34 & .26 \\
\hline $\begin{array}{l}\text { Moral-Cold } \\
\text { (b) }\end{array}$ & $\begin{array}{c}4.91 \\
(1.48)\end{array}$ & $\begin{array}{c}5.39 \\
(1.25)\end{array}$ & $\begin{array}{c}5.65 \\
(1.59)\end{array}$ & $\begin{array}{c}5.67 \\
(1.49)\end{array}$ & $\begin{array}{c}5.40 \\
(1.48)\end{array}$ & 1.98 & .23 \\
\hline $\begin{array}{l}\text { Immoral- } \\
\text { Warm (c) }\end{array}$ & $\begin{array}{c}3.14 \\
(1.46)\end{array}$ & $\begin{array}{c}3.27 \\
(1.49)\end{array}$ & $\begin{array}{c}3.26 \\
(1.78)\end{array}$ & $\begin{array}{c}3.21 \\
(1.29)\end{array}$ & $\begin{array}{c}3.22 \\
(1.50)\end{array}$ & .05 & .98 \\
\hline $\begin{array}{l}\text { Immoral- } \\
\text { Cold (d) }\end{array}$ & $\begin{array}{c}1.86 \\
(1.22)\end{array}$ & $\begin{array}{c}1.67 \\
(1.02)\end{array}$ & $\begin{array}{c}2.18 \\
(1.70)\end{array}$ & $\begin{array}{l}1.61 \\
(.93)\end{array}$ & $\begin{array}{c}1.83 \\
(1.26)\end{array}$ & 1.41 & .24 \\
\hline Subjects & 35 & 33 & 34 & 33 & 135 & - & - \\
\hline
\end{tabular}

Figure 1. Mean global impressions of the four endorsers, within-subjects analyses (H1)

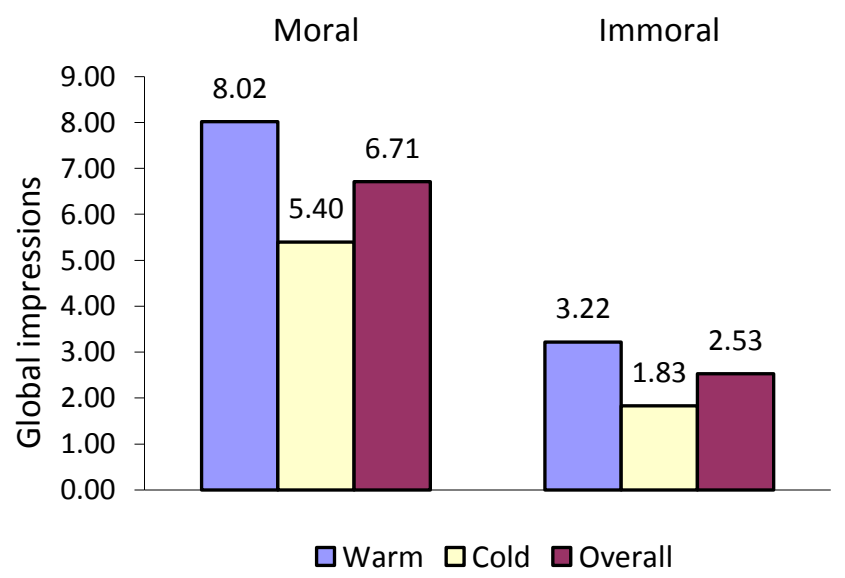

Source: Authors' own research. 
Further, between-subjects analyses examining just the first block of ratings across the four conditions revealed significant main effects of both moral character $\left(M_{\text {moral }}=6.55, M_{\text {immoral }}=2.44, F(1,131)=318.26, p<.001\right)$ and warmth information $\left(M_{\text {warm }}=5.49, M_{\text {cold }}=3.50, F(1,131)=74.26, p<.001\right)$ on endorser impressions. In comparison, moral character information was more impactful than warmth information on endorser impressions. Moreover, the moral-cold endorser was more favorably evaluated than immoral-warm endorser $\left(M_{\text {moral-cold }}=5.39, M_{\text {immoral-warm }}=\right.$ $3.26, t(65)=5.65, p<.001$; see Figure 2). These results between within- and between-subjects analyses were essentially identical.

Figure 2. Mean Global Impressions of the Four Endorsers, Between-Subjects Analyses (H1)

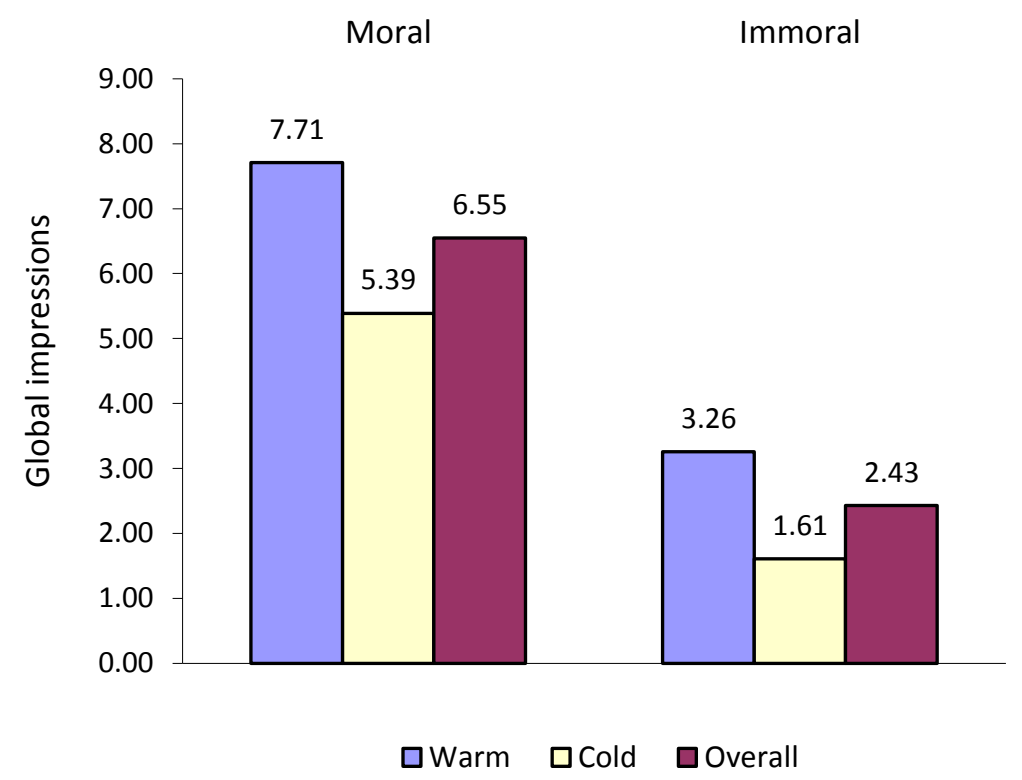

Source: Authors' own research.

In conclusion, these results demonstrated the greater causal impact of moral character information than warmth information on global endorser impressions. While both factors exerted salient impacts on global endorser impressions, moral character information was more impactful. As a result, hypothesis 1 was confirmed.

This study compared the dominance of moral character and warmth on endorser evaluations. However, it was not clear about how the dominance, along with perceiver characteristics (i.e., dispositional tendency, innate moral intuitions and self-location), moderated subsequent brand evaluations (H2, H3, H4 and H5). Therefore, the second study was conducted to answer these questions. Study 1 specifically examined the impact of endorser characteristics on endorser perception, whereas Study 2 verified the influence of perceiver characteristics on advertising and brand evaluations. 


\section{Study 2 \\ Method}

Materials

The hypothetical smartphone brand name, Appsung, was created based on the two major smartphone makers of Apple and Samsung for the ease of high quality association. Appsung V5 was the new brand extension of Appsung and was crafted as a high-quality brand with a pre-launch assessment in Consumer Reports' formats. D. C. and L. G. were two prospective endorsers for the Appsung V5. They were different in morality and warmth. D. C. was moral, but cold, whereas L. G. was warm, but immoral. Each of the four traits (i.e., moral, immoral, warm and cold) consisted of a list of five different adjectives. A pretest consisting of 43 U.S. residents (25 females, 18 males; $M_{\text {age }}=35.74, S D=11.77$ ) revealed that moral and immoral traits were positively and negatively rated, respectively $\left(M_{\text {moral }}=7.88, M_{\text {immoral }}=1.47, t(42)\right.$ $=22.54, p<.001)$. The same results are also for warm and cold traits $\left(M_{\text {warm }}=7.58\right.$, $\left.M_{\text {cold }}=1.81, t(42)=23.19, p<.001\right)$. The traits were rated with the global impression of endorser measure on a 9-point semantic differential scale anchored by "very negative (1)" and "very positive (9)" (Goodwin et al., 2014).

\section{Measures}

Self-location was measured with the dichotomous question of "Irrespective of what you know about biology, which body part do you more closely associate with your self?" with the two options of heart and brain (Fetterman and Robinson, 2013). The perceived quality of the Appsung V5 were captured with three 7-point semantic differential scales anchored by "undesirable (1)" /desirable (7)", "unfavorable (1)"/"favorable (7)", and "low quality (1)"/"high quality (7)," respectively (e.g., Kempf and Smith, 1998). The global impression of endorser was measured with a 7point semantic differential scale anchored by "very negative (1)" and "very positive (7)" (Goodwin et al., 2014). The perceived quality of advertising was identified with four 7-point semantic differential measures anchored by "unconvincing (1)" /"convincing (7)", "negative (1)" /"positive (7)”, "unreliable (1)" /"reliable (7)”, "inappropriate (1)" /“appropriate (7)," respectively (Homer, 1995; Singh et al., 2000; Till and Shimp, 1998).

The innate moral intuitions were measured with the ten selected statements of the 21-statement moral foundation measure (Graham et al., 2009). The selected 10-item MF measure on a 6-point Likert scale consists of two statements for each of the five morality elements of care, fairness, loyalty, authority, and purity. The rest of 11 items were not included as they were questions specifically measuring attitudes relevant to politics unrelated to this study. Finally, the dispositional tendency was captured with the 16-item dispositional attitude measure (DAM) on a 7-point semantic differential scale anchor by unfavorable/favorable (Hepler and Albarracín, 2013). 
Subjects, design and procedure.

The data was collected online via the M-Turk with Qualtrics questionnaires. As the research purpose was to verify the dominance of immoral character and cold traits, this study captured the dominance by directly comparing the global impressions of moral-cold and immoral-warm endorsers in a two-group between-subjects experimental design.

Overall, 72 U.S. residents (33 females, 39 males; $M_{\text {age }}=38.22, \mathrm{SD}=12.31$ ) participated in this study. The participants were informed that the purpose of study was to investigate consumers' opinions about brand endorsers. They started the participation by answering the first question identifying self-location (Fetterman and Robinson, 2013), followed by reading and rating the statement of the Appsung V5. Then, they were informed that D. C. or L. G. was the prospective endorser for the Appsung V5. Based on the personality traits (i.e., moral-cold or immoral-warm), they rated the prospective endorser and re-evaluated the Appsung V 5 endorsed by the endorser. Finally, they answered the 10-item MF and 16-item DAM scales measuring their innate moral intuitions and dispositional tendency, respectively.

\section{Manipulation check}

As the scale reliability analyses on the multiple-item measures of advertising and brand attitudes yielded high reliabilities ( $\alpha$ s $>.81$ ), the advertising and brand attitude indices were formulated by averaging the scores of the multiple items. The brand quality change index was captured by comparing the difference between the prior and posterior brand quality indices. One-way ANOVA on the prior brand quality index revealed that the participants of the two experimental groups evaluated the Appsung V5 brand equally $\left(M_{\text {group } 1}=6.34, M_{\text {group } 2}=6.40, F(1,70)=.09\right.$, $p>.10$ ), which yielded no conditional effects.

\section{Test of hypotheses: endorser characteristics}

Hypothesis 2 states that immoral character instigates more negative impacts than coldness on advertising and brand evaluations. Paired-samples t-tests revealed that both the moral-cold $\left(M_{\text {prior }}=6.34, M_{\text {posterior }}=5.61, t(34)=-4.79, p<.001\right)$ and warmimmoral $\left(M_{\text {prior }}=6.40, M_{\text {posterior }}=5.06, t(36)=-6.02, p<.001\right)$ endorsers significantly weakened the endorsed brand. The results suggested that both moral character and warmth were important endorser characteristics for endorsed brand evaluations. Moreover, one-way ANOVA on the advertising attitude index revealed that respondents less favored the advertising endorsed by the warm-immoral endorser $\left(M_{\text {warm-immoral }}=4.13, M_{\text {moral-cold }}=5.26, F(1,70)=13.25, p<.001\right)$. One-way ANOVA on the brand quality change index revealed that the warm-immoral endorser exerted more negative attitude change on the endorsed brand $\left(M_{\text {warm-immoral }}=-1.27, M_{\text {moral }}\right.$ cold $=-.72, F(1,70)=4.28, p<.05$; see Figure 3$)$. The results indicated that negative moral character (or immorality) information was more detrimental than negative warmth (or coldness) information to advertising and endorsed brand evaluations. Thus, hypothesis 2 was confirmed. 
Figure 3. The dominance of negative endorser traits on brand evaluations (H2)

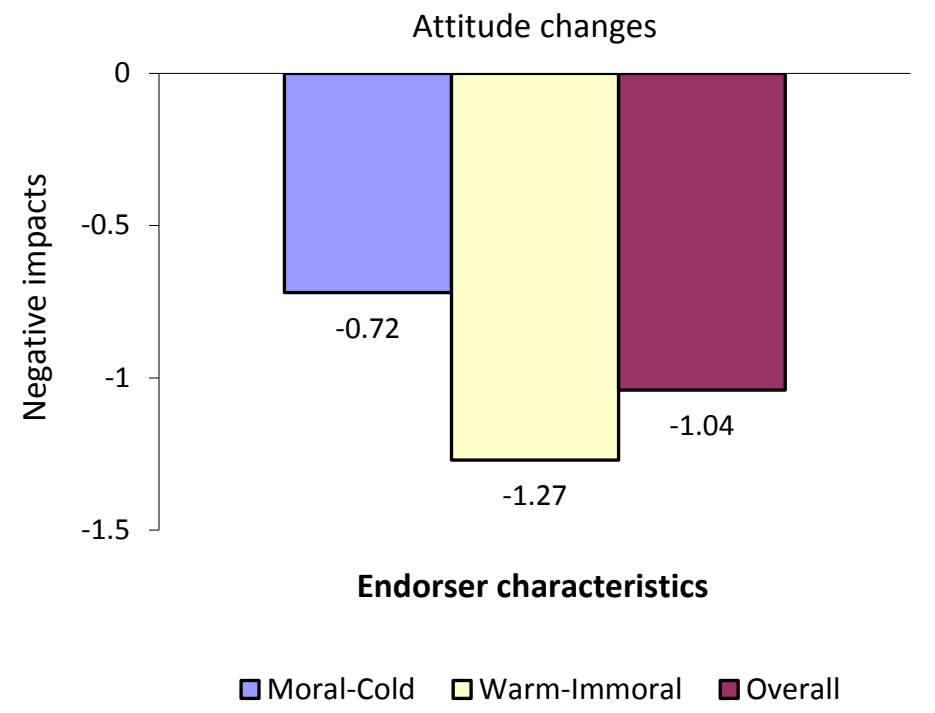

Source: Authors' own research.

\section{Test of hypotheses: perceiver characteristics}

Hypothesis 3 states that perceivers with negative (vs. positive) dispositional tendency more (vs. less) unfavorably evaluate the brands endorsed by tarnished endorsers (H3a). However, the tarnished endorser information instigates identical negative impacts on positive and negative dispositional tendency perceivers' brand evaluations (H3b). One-way ANOVA on the advertising and prior and posterior brand quality indices revealed that low- and high-DAM respondents had similar attitudes toward the tarnished endorsers $\left(M_{\text {low }}=4.52, M_{\text {high }}=4.70, F(1,70)=.93, p\right.$ $>.10)$, the Appsung V5 advertising $\left(M_{\text {low }}=4.57, M_{\text {high }}=4.81, F(1,70)=.49, p>.10\right)$ and the Appsung V5 brand before $\left(M_{\text {low }}=6.49, M_{\text {high }}=6.26, F(1,70)=1.68, p>.10\right)$ and after $\left(M_{\text {low }}=5.40, M_{\text {high }}=5.29, F(1,70)=.13, p>.10\right)$ the experimental treatment, which led to similar brand attitude change $\left(M_{\text {low }}=-1.09, M_{\text {high }}=-.97, F(1,70)=.18, p\right.$ $>$.10; see Figure 4). The results suggested that consumers with positive and negative dispositional tendency evaluated tarnished celebrity endorsers, the brands prior to the endorsement, and the advertising and brands endorsed by the tarnished endorsers identically. As a result, the tarnished endorser information identically weakened the brand attitude of positive and negative dispositional tendency perceivers. Thus, the third hypothesis was not confirmed. 
Figure 4. The moderation of dispositional tendency on brand evaluations (H3)

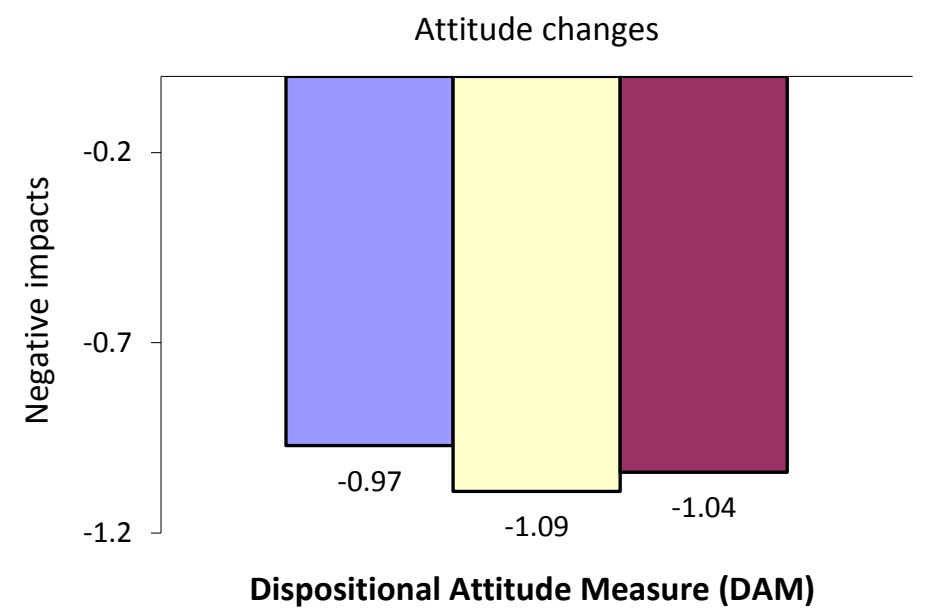

$\square$ High-DAM $\square$ Low-DAM 口Overall

Source: Authors' own research.

Further, hypothesis 4 states that high- (vs. low-) morality perceivers more (vs. less) unfavorably evaluate tarnished celebrity endorsers and the advertising and brands endorsed by the tarnished endorsers. One-way ANOVAs on the indices of endorser attitudes, advertising attitudes, and brand attitude change yielded a marginal significant MF effect $\left(M_{\text {low }}=-.79, M_{\text {high }}=-1.30, F(1,70)=3.47, p=.067\right.$; see Figure 5) on brand attitude change and insignificant MF effect on the evaluations of endorser $\left(M_{\text {low }}=4.70, M_{\text {high }}=4.51, F(1,70)=1.10, p>.10\right)$ and advertising $\left(M_{\text {low }}=\right.$ $\left.4.74, M_{\text {high }}=4.58, F(1,70)=.23, p>.10\right)$. The results indicated that high- (vs. low-) morality perceivers were more vulnerable to the brand endorsed by a tarnished celebrity. Thus, hypothesis 4 was partially confirmed.

Figure 5. The moderation of moral intuitions on brand evaluations (H4)

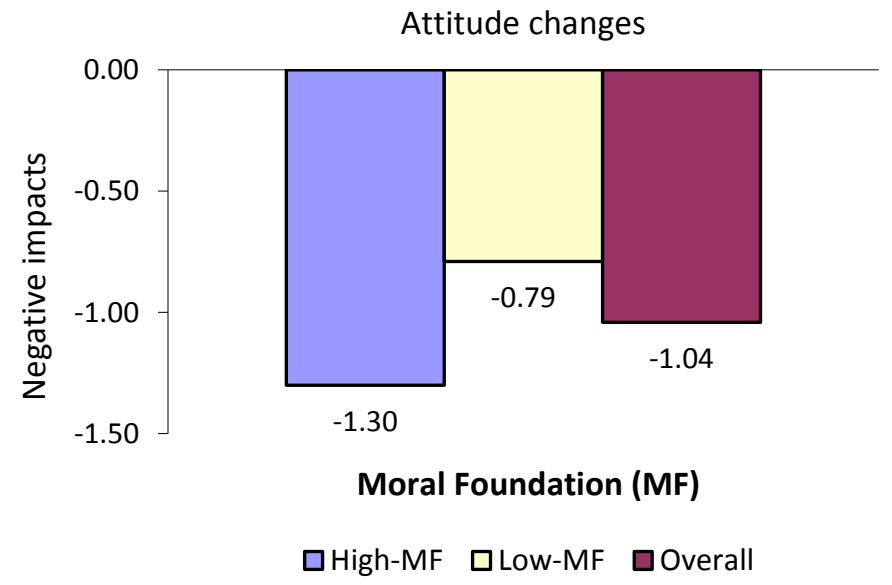

Source: Authors' own research. 
Moreover, hypothesis 5 states that heart- (vs. brain-) locators more unfavorably evaluate tarnished celebrity endorsers and the advertising and brands endorsed by the tarnished endorsers. As with the analyses for MF, the analyses yielded a marginal significant SL effect $\left(M_{\text {heart }}=-1.37, M_{\text {brain }}=-.84, F(1,70)=3.44, p\right.$ $=.068$; see Figure 6) and insignificant SL effects on the evaluations of endorser $\left(M_{\text {heart }}=4.54, M_{\text {brain }}=4.66, F(1,70)=.41, p>.10\right)$ and advertising $\left(M_{\text {heart }}=4.69\right.$, $\left.M_{\text {brain }}=4.64, F(1,70)=.02, p>.10\right)$. The results indicated that heart- (vs. brain-) locators were more vulnerable to the brand endorsed by a tarnished celebrity. Thus, hypothesis 5 was partially confirmed.

Figure 6. The moderation of self-location on brand evaluations (H5)

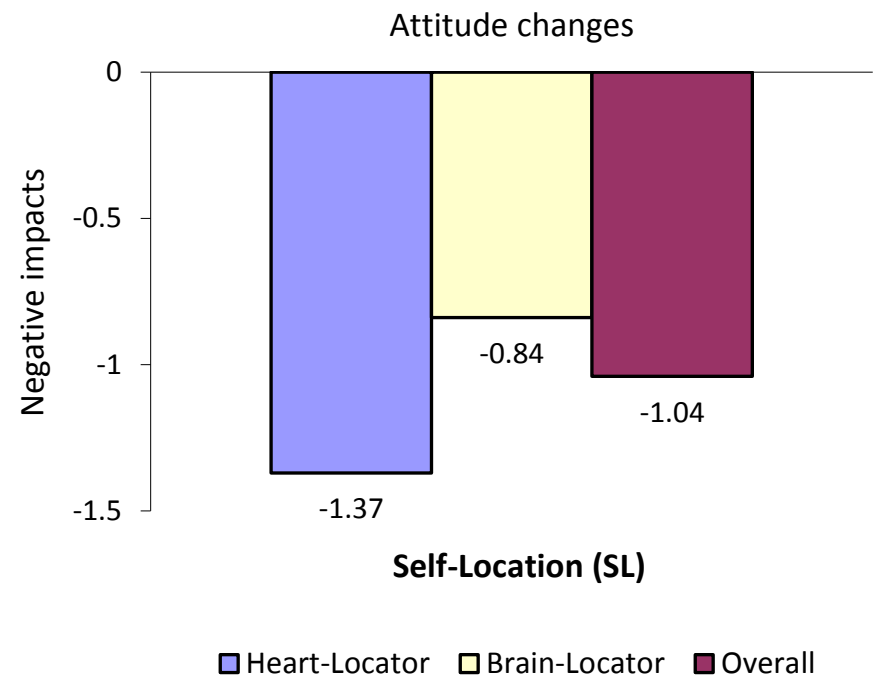

Source: Authors' own research.

\section{Discussion}

In conclusion, moral character (vs. warmth) dominates, and instigates more impacts on, endorsers, advertising, and brand evaluations, while both moral character and warmth are important characteristics of celebrity endorsers. Tarnished endorsers with immoral character (vs. coldness) are more detrimental to endorser, advertising, and brand evaluations, while both the tarnished endorsers with immoral character and coldness significantly weaken the endorsed brand quality. Moreover, dispositional tendency yields insignificant influences on endorser, advertising, and brand evaluations. However, innate moral intuitions and self-location moderate brand evaluations. High- (vs. low-) morality consumers and heart- (vs. brain-) locators are more vulnerable to, and more unfavorably evaluate, the brands endorsed by tarnished endorsers.

\section{Discussion and conclusions}

This research contributes endorsement research by advancing the research scope in the three perspectives of endorser, perceiver, and culture characteristics. This 
research compares (a) the dominance of endorsers' immoral character and cold traits and (b) the moderation of the dispositional tendency, innate moral intuitions, and self-location on advertising and brand evaluations. The implications based on the research findings are discussed as follows.

\section{Endorser characteristics - moral character and warmth}

The research findings reveal that moral character dominates warmth endorser, advertising, and brand evaluations. Information about celebrity endorsers tarnished in moral character or warmth weakens the evaluations of celebrity endorsers, advertising, and brands. The results suggest that both the moral character and warmth traits are important endorser characteristics. However, in comparison, moral character is more influential than warmth on endorser, advertising, and brand evaluations. Negative moral (i.e., immoral) character information reduces the favorability of endorsers, advertising, and brands more than does the negative warmth (or coldness) information. The research findings parallel the findings in person perception (Goodwin et al., 2014). Moral character appears a prime and dominating characteristic in endorser perception, as well as the subsequent evaluations of advertising and brands.

\section{Perceiver characteristics - dispositional tendency}

While evaluating brands differently in extent, the perceptual norms of perceivers with positive and negative dispositional tendency are identical. In comparison, the perceptual norms of perceivers with positive and negative dispositional tendency are relatively more positively and negatively anchored, respectively (Hepler and Albarracín, 2013). In other words, while negative (vs. positive) dispositional tendency perceivers tend to more (vs. less) unfavorably evaluate brands, the dispositional tendency doesn't imply that negative (vs. positive) dispositional tendency perceivers are more (vs. less) sensitive to, and yield more (vs. less) brand attitude change. In other words, perceivers with positive and negative dispositional tendency yield identical attitude changes on brand evaluations. Perceivers with negative (vs. positive) dispositional tendency both more (vs. less) unfavorably evaluate the brands before and after the impact of the tarnished endorsers. The difference in prior brand evaluations between the perceivers with positive and negative dispositional tendency is counterbalanced by the difference in posterior brand evaluations.

In contrast, analytic-thinking focus on endorser characteristics for their judgments. The endorser trait information outweighs the impact of dispositional tendency on judgments. As a result, endorser trait information and dispositional tendency exert significant and insignificant influences on judgments, respectively, including advertising and prior and posterior brand evaluations.

\section{Perceiver characteristics - moral intuitions}

The research findings indicate that innate moral intuitions moderate brand evaluations. Consumers with high moral intuitions (or high MF) more unfavorably 
evaluate advertising and brands endorsed by tarnished endorsers. The findings enhance the innate moral intuition theory depicting that moral intuitions provide subjects with the moral foundations to build on as they transmit cultural values and make social judgment (Marcus, 2004), including brand evaluations.

\section{Perceiver characteristics - self-location}

The findings indicate that self-location moderates brand evaluations. Heart-locators are more sensitive to tarnished endorser information and more unfavorably evaluate the endorsed brands. The findings reinforce the metaphor representation theory (Lakoff and Johnson, 1999). The theory depicts that body metaphors are consequential in understanding individual differences in perception and behaviors (Fetterman and Robinson, 2013), including brand evaluations. Heart-locators are thought to be emotional, feminine, and warm and more favor emotional considerations, whereas brain-locators are thought to be rational, logical, and cold and more favor rational considerations. As a result, tarnished endorser information instigates more salient negative impacts on heart-locators' brand evaluations.

In conclusion, the impacts of dispositional tendency, innate moral intuitions, and self-location are different. Innate moral intuitions and self-location moderate brand evaluations. Advertising endorsed by tarnished endorsers exerts more negative impacts on consumers with heart-location or higher moral intuitions.

\section{Limitations and future research}

This study has three specific limitations, which demand further clarification with future research. First, research in celebrity endorsements depicts that celebrity effectiveness is product dependent (Belch and Belch, 2013; Friedman and Friedman, 1979; McCracken, 1989). McCracken's (1989) meaning transfer model suggests that celebrity endorsers generate better effects for emotional or image relevant products with high social and/or psychological risks (e.g., fashion apparel, cosmetics, costume jewellery). In contrast, professional experts work better for functional products with high financial and/or performance risks (e.g., consumer electronics, pharmaceuticals). The findings of this research are based on the smartphone, which is mainly a functional product, while partially emotion or image relevant. It is unknown whether the endorser effects on emotional or image relevant products to be different. Thus, further research can be conducted to clarify this issue.

Second, this research compares the dominance of moral character and warmth, which are the prime personality traits for person perception. Research on person perception also documents that warmth and competence are two roughly orthogonal dimensions of personality underlie person perception (e.g., Fiske et al., 2007; Fiske et al., 2002). Moral character information is conceived of as a subcomponent of warmth (Cuddy et al., 2008), but is recently verified as a primary dimension dominating person perception and evaluations over the warmth trait. Moreover, research on endorser characteristics documents that competence (or expertise) is a primary characteristic of athletic celebrity endorsers for athletic functional products (Belch and Belch, 2013). Competence appears an endorser 
characteristic competing against moral character. Therefore, further research can be conducted to examine the perceiver effects of dispositional tendency, moral intuitions, and self-location on the dominance of moral character and competence of athletic celebrity endorsers for athletic products.

Finally, extant research in cross-cultural advertising documents unparalleled responses to advertising appeals between easterners and westerners (e.g., Jung et al., 2009). Youth segments of easterners in higher power distance cultures (e.g., Korea, Thailand) yield a value paradox phenomenon, where consumers' observed behaviors (i.e., the desired) are opposite to their cultural values (the desirable; Jung et al., 2009). The findings suggest that traditional cultural characteristics (e.g., power distance, holistic-analytic thinking) are insufficient deciphers for the consumption behaviors of youth segments. Therefore, further research should investigate the interplay of ages and the investigated perceiver characteristics on the dominance of moral character.

\section{References}

Ahluwalia, R., Burnkrant, R.E. and Unnava, H.R. (2000), "Consumer response to negative publicity: The moderating role of commitment", Journal of Marketing Research, Vol. 37, No. 2, pp. 203-214.

Amos, C., Holmes, G. and Strutton, D. (2008), "Exploring the relationship between celebrity endorser effects and advertising effectiveness", International Journal of Advertising, Vol. 27, No. 2, pp. 209-234.

Bartz, S., Molchanov, A. and Stork, P.A. (2013), "When a celebrity endorser is disgraced: A twenty-five-year event study", Marketing Letter, Vol. 24, No.2, pp. 131-141.

Belch, G.E. and Belch, M.A. (2013), "A content analysis study of the use of celebrity endorsers in magazine advertising", International Journal of advertising, Vol. 32, No. 3, pp. 369-389.

Carrillat, F.A., D'Astous, A. and Lazure, J. (2013), "For better, for worse? What to do when celebrity endorsements go bad", Journal of Advertising Research, Vol. 53, No. 1, pp. 15-30.

Chang, C. (2010), "Making unique choices or being like others: How priming selfconcepts influences advertising effectiveness", Psychology \& Marketing, Vol. 27, No. 4, pp. 399-416.

Cuddy, A.J.C., Fiske, S.T. and Glick, P. (2008), "Warmth and competence as universal dimensions of social perception: The stereotype content model and the BIAS Map", Advances in Experimental Social Psychology, Vol. 40, pp. 61-149.

Eisend, M. and Langner, T. (2010), "Immediate and delayed advertising effects of celebrity endorsers' attractiveness and expertise", International Journal of Advertising, Vol. 29, No. 4, pp. 527-546.

Fetterman, A.K. and Robinson, M.D. (2013), "Do you use your head or follow your heart? Self-location predicts personality, emotion, decision making, and 
performance", Journal of Personality and Social Psychology, Vol. 105, No. 2, pp. 316-334.

Fiske, S. T., Cuddy, A. J. C. and Glick, P. (2007), "Universal dimensions of social cognition: Warmth and competence", Trends in Cognitive Sciences, Vol. 11, No. 2, pp. 77-83.

Fiske, S.T., Cuddy, A.J.C., Glick, P. and Xu, J. (2002), "A model of (often mixed) stereotype content: Competence and warmth respectively follow from perceived status and competition", Journal of Personality and Social Psychology, Vol. 82, No. 6, pp. 878-902.

Fleck, N., Korchia, M. and le Roy, I. (2012), "Celebrities in advertising: Looking for congruence or likability?", Psychology \& Marketing, Vol. 29, No. 9, pp. 651662.

Fong, C.P.S. and Wyer, Jr., R.S. (2012), “Consumers' reactions to a celebrity endorser scandal", Psychology and Marketing, Vol. 29, No. 11, pp. 885-896.

Friedman, H. H. and Friedman, L. (1979), "Endorser effectiveness by product type", Journal of Advertising Research, Vol. 19, pp. 63-71.

Goodwin, G.P., Piazza, J. and Rozin, P. (2014), "Moral character predominates in person perception and evaluation", Journal of Personality and Social Psychology, Vol. 106, No. 1, pp. 148-168.

Graham, J., Haidt, J. and Nosek, B.A. (2009), "Liberals and conservatives rely on different sets of moral foundations", Journal of Personality and Social Psychology, Vol. 96, No. 5, pp. 1029-1046.

Hepler, J. and Albarracín, D. (2013), "Attitudes without objects: Evidence for a dispositional attitude, its measurement, and its consequences", Journal of Personality and Social Psychology, Vol. 104, No. 6, pp. 1060-1076.

Homer, P.M. (1995), "Ad size as an indicator of perceived advertising costs and effort: The effects on memory and perceptions", Journal of Advertising, Vol. 24, No. 4, pp. 1-12.

Jung, J.M., Polyorat, K. and Kellaris, J.J. (2009), "A cultural paradox in authority-based advertising", International Marketing Review, Vol. 26, No. 6, pp. 601-632.

Kahle, L.B. and Homer, P. M. (1985), "Physical attractiveness of celebrity endorsers: A social adaptation perspective", Journal of Consumer Research, Vol. 11, No. 4, pp. 954-961.

Kareklas, I., Carlson, J.R. and Muehling, D.D. (2012), "The role of regulatory focus and self-view in green advertising message FDAMing", Journal of Advertising, Vol. 41, No. 4, pp. 25-39.

Kempf, D.S. and Smith, R.E. (1998), "Consumer processing of product trial and the influence of prior advertising: A structural modeling approach", Journal of Marketing Research, Vol. 35, No. 3, pp. 325-338.

Knittel, C.R. and Stango, V. (2014), "Celebrity endorsements, firm value, and reputation risk: Evidence from the Tiger Woods scandal", Management Science, Vol. 60, No. 1, pp. 21-37.

Kupperman, J. (1991), Character, Oxford University Press: New York.

Lakoff, G. (1986), "A figure of thought", Metaphor \& symbolic qctivity, Vol. 1, No. 3, pp. 215-225. 
Lakoff, G. and Johnson, M. (1999), Philosophy in the flesh: The embodied mind and its challenge to Western thought. Basic Books: New York.

Landau, M.J., Meier, B.P. and Keefer, L.A. (2010), "A metaphor-enriched social cognition", Psychological Bulletin, Vol. 136, No. 6, pp. 1045-1067.

Lee, J.S., Kwak, D.H. and Braunstein-Minkove, J.R. (2016), “Coping with endorsers' immoral behavior: Roles of identification and moral emotions on moral reasoning strategies", Journal of Sport Management, Vol. 30, No. 2, pp. 176191.

Lee, J.S., Kwak, D.H. and Moore, D. (2015), "Athletes' transgressions and sponsor evaluations: A focus on consumers' moral reasoning strategies", Journal of Sport Management, Vol. 29, No. 6, pp. 672-687.

Lee, Y. and Koo, J. (2015), "Athlete endorsement, attitudes, and purchase intention: The interaction effect between endorser-product congruence and endorser credibility", Journal of Sport Management, Vol. 29, No. 5, pp. 523-538.

Liu, M.T. and Brock, J.L. (2011), "Selecting a female endorser in China", European Journal of Marketing, Vol. 45, No. 7-8, pp. 1214-1235.

Louie, T.A., Kulik, R.L. and Jacobson, R. (2001), "When bad things happen to the endorsers of good products", Marketing Letters, Vol. 12, No. 1, pp. 13-23.

Louie, T.A., Obermiller, C. (2002), "Consumer response to a firm's endorser (dis)association decisions", Journal of Advertising, Vol. 31, No. 4, pp. 41-52.

Marcus, G. (2004), The birth of the mind, Basic Books: New York, NY.

McCracken, G. (1989), "Who is the celebrity endorser? Cultural foundations of the endorsement process", Journal of Consumer Research, Vol. 16, No. 3, pp. 310321.

Money, B.R., Shimp, T.A. and Sakano, T. (2006), "Celebrity endorsements in Japan and the United States: Is negative information all that harmful?", Journal of Advertising Research, Vol. 46, No. 1, pp. 113-123.

Ohanian, R. (1990), "Construction and validation of a scale to measure celebrity endorsers' perceived expertise, trustworthiness, and attractiveness", Journal of Advertising, Vol. 19, No. 3, pp. 39-52.

Ohanian, R. (1991), "The impact of celebrity spokespersons' perceived image on consumers' intention to purchase", Journal of Advertising Research, Vol. 31, No. 1 , pp. 46-54.

Park, J.K. and Roedder John, D. (2012), "Capitalizing on brand personalities in advertising: The influence of implicit self-theories on ad appeal effectiveness", Journal of Consumer Psychology, Vol. 32, No. 3, pp. 424-432.

Petty, R.E., Cacioppo, J.T. and Schumann, D. (1983), "Central and peripheral routes to advertising effectiveness: The moderating role of involvement", Journal of Consumer Research, Vol. 10, No. 2, pp. 135-146.

Pikas, B., Schied, R. and Pikas, A. (2012), "Assessing the qualities of endorsers: A study of consumer preferences for the three qualities of sports endorsers attractiveness, trustworthiness, and expertise", Journal of Marketing Development and Competitiveness, Vol. 6, pp. 42-55. 
Polyorat, K. and Alden, D.L. (2005), "Self-construal and need-for-cognition effects on brand attitudes and purchase intentions in response to comparative advertising in Thailand and the United States", Journal of Advertising, Vol. 34, No. 1, pp. 37-48.

Rice, D.H., Kelting, K. and Lutz R.J. (2012), "Multiple endorsers and multiple endorsements: The influence of message repetition, source congruence and involvement on brand attitudes", Journal of Consumer Psychology, Vol. 22, No. 2, pp. 249-259.

Richerson, P. J. and Boyd, R. (2005), Not by genes alone: How culture transformed human evolution, University of Chicago Press: Chicago, IL.

Shapiro, S. and Krishnan, H.S. (2001), "Memory-based measures for assessing advertising effects: A comparison of explicit and implicit memory effects", Journal of Advertising, Vol. 30, No. 3, pp. 1-13.

Singh, S.N., Lessig, V. P., Kim, D., Gupta, R. and Hocutt, M.A. (2000), "Does your ad have too many pictures?", Journal of Advertising Research, Vol. 40, pp. 11-27.

Silvera, D.H. and Austad, B. (2004), "Factors predicting the effectiveness of celebrity endorsement advertisements", European Journal of Marketing, Vol. 38, No. 11-12, pp. 1509-1526.

Spry, A., Pappu, R. and Cornwell, T.B. (2011), "Celebrity endorsement, brand credibility and brand equity", European Journal of Marketing, Vol. 45, No. 6, pp. 882-909.

Thwaites, D., Lowe, B., Monkhouse, L.L. and Barnes, B.R. (2012), "The impact of negative publicity on celebrity ad endorsements", Psychology \& Marketing, Vol. 29, No. 9, pp. 663-673.

Till, B.D. and Shimp, T.A. (1998), "Endorsers in advertising: the case of negative celebrity information", Journal of Advertising, Vol. 27, No. 1, pp. 67-82.

Tsai, W.H. and Tsai, S. (2011), "How minority consumers use targeted advertising as pathways to self-empowerment", Journal of Advertising, Vol. 40, No. 3, pp. 8597.

Turiel, E. (1983), The development of social knowledge: Morality and convention, Cambridge University Press: Cambridge, United Kingdom.

Um, N.-H. (2013), "Celebrity scandal fallout: How attribution style can protect the sponsor", Psychology \& Marketing, Vol. 30, No. 6, pp. 529-541.

Wang, C.L., Bristol, T., Mowen, J.C. and Chakraborty, G. (2000), "Alternative modes of self-construal: dimensions of connectedness-separateness and advertising appeals to the cultural and gender-specific self", Journal of Consumer Psychology, Vol. 9, No. 2, pp. 107-115.

Zhang, J. (2009), "The effect of advertising appeals in activating self-construals: A case of bicultural Chinese Generation X consumers", Journal of Advertising, Vol. 38, No. 1, pp. 63-81.

Zhang, L., Moore, M. and Moore, R. (2011), "The effect of self-construals on the effectiveness of comparative advertising", Marketing Management Journal, Vol. 21, No. 4, pp. 195-206. 